\title{
The Military and the Fight Against Serious Crime: Lessons from the Balkans
}

\author{
Cornelius Friesendorf*
}

Serious crime poses major obstacles in peace operations. International actors intervening in war-torn countries face the challenge of putting pressure on suspected war criminals, members of organized criminal groups, those who instigate interethnic violence, and corrupt officials. While it is widely acknowledged by now that serious crime and public security gaps cause lasting damage to international stabilization efforts, international and domestic policing structures remain weak. This article examines the law enforcement role of international military forces. It shows that in post-war BosniaHerzegovina and Kosovo, military support for crime-fighting efforts has been unsystematic, although it has improved over time. Practical, political, and normative reasons stand in the way of employing the military for law enforcement tasks. However, under conditions of weak policing, preparing the military for law enforcement is necessary in order to better protect citizens against serious crime.

\section{Introduction}

Whether or not to use the military to assist in law enforcement is a major dilemma in peace operations. ${ }^{1}$ International police forces are generally unable to prevent or punish serious criminal acts such as interethnic violence and organized crime. Domestic security forces are either absent or are themselves sources of insecurity. The onus of filling public security gaps and of fighting serious crime therefore falls on international military forces. ${ }^{2}$ However, the military is reluctant to take on the responsibility for fighting crime, and is also not particularly good at it. Equally important, the principles of Security Sector Reform (SSR) prescribe the separation of military from policing functions. Using the military for law enforcement tasks is therefore a tough choice.

This article focuses on post-war Bosnia-Herzegovina (in the following referred to as Bosnia) and Kosovo. It shows that decision-makers and practitioners in these two "international protectorates" have dealt with this dilemma in an ad hoc, unsystematic way. This is not only (nor even primarily) the fault of NATO and/or EU military forces. Instead, unsystematic crime fighting by the military represents a general failure

* Dr. Cornelius Friesendorf is currently a lecturer and research fellow at Goethe University in Frankfurt am Main and at the Peace Research Institute Frankfurt. His most recent book is The Military and Law Enforcement in Peace Operations: Lessons from Bosnia-Herzegovina and Kosovo (Vienna and Geneva: LIT and DCAF, 2010).

1 For an extended discussion of the views advanced in this article, see Cornelius Friesendorf, The Military and Law Enforcement in Peace Operations: Lessons from Bosnia-Herzegovina and Kosovo (Vienna and Geneva: LIT and DCAF, 2010).

2 On security gaps, see Robert B. Oakley, Michael Dziedzic, and Eliot M. Goldberg, eds., Policing the New World Disorder: Peace Operations and Public Security (Washington D.C.: National Defense University Press, 1998). 
on the part of states and international organizations that intervene in war-torn countries to protect people from violence. There was and there is no panacea for stabilizing wartorn countries or for countering rioters, "ethnic cleansers," war profiteers, and corrupt officials. But if the military had intervened more systematically in many conflict arenas, lives would have been saved, and faster progress would have been made in overcoming the legacies of violence and crime that continue to haunt Bosnia and Kosovo.

Systematic military involvement in law enforcement, as called for in this article, often means more military involvement in law enforcement, including direct participation. This is particularly the case during the early stages of post-war intervention, when the weakness of local police forces is most apparent and when security conditions are inimical to the application of civilian policing strategies. ${ }^{3}$ This article shows that the reluctance of international military forces to engage in what civilian and military officials continue to regard as policing tasks has been very costly. But the military can also be guilty of trying to do too much, and can engage in belated activism.

Three caveats are in order. First, the article supports the SSR principles of separating the military from the police, and of giving primacy to the police in internal security. But calls for the deployment of more international civilian police (CIVPOL), though growing ever louder, are still not being heeded. Rethinking the role of the military in peace operations is therefore crucial. Second, the use of coercive strategies against "spoilers" of post-conflict stabilization is necessary for stabilization efforts to succeed, but it is not sufficient. Economic reconstruction and social reconciliation are equally important for building sustainable peace. Even better, conflict prevention should be prioritized. Third, terms such as "law enforcement," "serious crime," and "organized crime" oversimplify a complex reality. The assumptions inherent in these concepts are culturally and temporally contingent, reflecting the interests and prejudices of influential actors. ${ }^{4}$ This paper defines "serious crime" as criminal acts that destabilize reconstruction and peace-building efforts. ${ }^{5}$

The first section of this article examines the need to close post-war public security gaps, and addresses the dilemma posed by using military forces to achieve this goal. The second section analyzes the performance of NATO and EU military forces in the fight against serious crime in Bosnia. The third section focuses on the role of NATO in post-war Kosovo. In a last step, drawing on the results from the two empirical illustrations, the article suggests steps for improving military support to law enforcement in war-torn countries.

3 See David H. Bayley and Robert M. Perito, The Police in War: Fighting Insurgency, Terrorism, and Violent Crime (Boulder, CO: Lynne Rienner, 2010).

4 See Peter Andreas and Ethan Nadelmann, Policing the Globe: Criminalization and Crime Control in International Relations (Oxford: Oxford University Press, 2006).

5 See also Colette Rausch, ed., Combating Serious Crimes in Postconflict Societies: A Handbook for Policymakers and Practitioners (Washington, D.C.: United States Institute of Peace Press, 2006). 


\section{Security Gaps and the Military}

The distinction between military and policing functions is an important feature of the modern democratic state. It reflects another distinction, that between internal and external security. The military is assigned the responsibility to protect the state and society from external security threats, whereas the police are given primary responsibility over internal security.

There are good reasons for why the military should not become embroiled in policing tasks. ${ }^{6}$ Soldiers tend to think in terms of friend and foe. They are trained and equipped to use overwhelming force to secure victory. Secrecy is highly valued. Also, soldiers tend to live and act at a certain remove from normal society. Police, by contrast - and especially regular police forces - interact with citizens on a day-to-day basis, are trained to use minimal violence, and can therefore inspire public trust. ${ }^{7}$ Evidence collection and handling is a central police task aimed at the successful prosecution of alleged criminals. Employing the military domestically is therefore not only problematic because the democratic norms of criminal justice are likely to be violated, but also because the military lacks the requisite technical policing skills.

Divisions of labor between the military, the police, and intelligence agencies are increasingly breaking down, however. Even during the Cold War, the state model stressing the distinction between military and policing tasks was an ideal-type. For example, as part of the "war on drugs," the United States employed military force to fight the illicit drug industry abroad (e.g., in Colombia). At home, counter-drug operations carried out by the National Guard became more frequent, while the police was paramilitarized. ${ }^{8}$ In Northern Ireland, the British armed forces were deeply involved in the fight against the Irish Republican Army. Other countries, such as Italy, France, and Spain, have had gendarmerie forces for a long time. ${ }^{9}$ Even countries such as Germany, where the division of labor between the military and the police as well as strict provisions against the creation of a political policing apparatus reflect historical experiences, saw a need to strengthen their police forces to cope with terrorism in the 1970s.

The end of the Cold War served as a catalyst for efforts to establish democratic control over security forces in former Communist countries. Promoting a division of

6 See Karl W. Haltiner, "Policemen or Soldiers? Organizational Dilemmas of Armed Forces in Peace Support Operations," in The Challenging Continuity of Change and the Military: $\mathrm{Fe}$ male Soldiers, Conflict Resolution, South Africa, ed. Gerhard Kümmel (Strausberg: Sozialwissenschaftliches Institut der Bundeswehr, 2001), 359-84.

7 Eirin Mobekk, "Identifying Lessons in United Nations International Policing Missions," DCAF Policy Paper No.9 (Geneva: Geneva Centre for the Democratic Control of Armed Forces, November 2005), 5-6.

8 Peter B. Kraska, "Militarization and Policing - Its Relevance to $21^{\text {st }}$ Century Police," Policing 1:4 (2007): 501-13.

9 Derek Lutterbeck, "Between Police and Military: The New Security Agenda and the Rise of Gendarmeries," Cooperation and Conflict 39:1 (2004): 45-68; Doron Zimmermann, "Between Minimum Force and Maximum Violence: Combating Political Violence Movements with Third-Force Options," Connections: The Quarterly Journal 4:1 (2005): 43-60. 
labor between the military and the police became a central tenet of SSR, a concept developed in the late 1990s that built upon earlier strategies of democratization and that has evolved into a crucial element of post-conflict stabilization efforts. ${ }^{10}$ One SSR expert writes that, "in principle it is undesirable that the military should be involved in civilian law enforcement." ${ }^{11}$ Similarly, the SSR handbook of the Organization for Economic Cooperation in Europe (OECD) stresses that the military "should only be used in highly exceptional and well defined circumstances (for example, during a state of emergency); either under the direction of the police or in joint command of operation." 12

But paradoxically, the end of the Cold War also spurred a countervailing trend, whereby military-police relations were blurring, reflecting a conceptual and empirical collapse of the distinction between internal and external security. As the Iron Curtain was lifted, and as globalization redefined time and space, diffuse security risks partially replaced the military threat spectrum that had hitherto defined international security. Terrorism and organized crime became increasingly transnational and networked. ${ }^{13}$ Problems whose causes lay partially abroad therefore had an impact at home. In addition, internal warfare became the predominant type of war. Such wars are characterized by the victimization of civilians, a breakdown of law and order, the collapse of state institutions, and pervasive criminality. Effects such as the migration of refugees to safer places are felt beyond the borders of collapsing states.

These and other dynamics accelerated the broadening of military tasks, the constabularization of the military, the internationalization and paramilitarization of the police, and the reorientation of intelligence agencies. ${ }^{14}$ States have increasingly been trying to integrate their internal and external security instruments. With regard to armed forces, European militaries are now being used for a variety of purposes, including disaster relief, the delivery of humanitarian aid, and also law enforcement support. As Ehrhart and Schnabel write,

Traditional functions of national defense and deterrence give way to, or are complemented with, capacities to engage in conflict prevention, peace enforcement, peacekeeping and the restoration of security and order. In this context, the main goal of mili-

10 Heiner Hänggi, "Security Sector Reform," in Post-Conflict Peacebuilding: A Lexicon, ed. Vincent Chetail (Oxford: Oxford University Press), 337-49.

11 Hans Born, ed., IPU-DCAF Handbook on Parliamentary Oversight of the Security Sector: Principles, Mechanisms and Practices (Geneva: DCAF, 2003), 54.

12 Organization for Economic Cooperation and Development (OECD), The OECD DAC Handbook on Security System Reform (SSR): Supporting Security and Justice (Paris: OECD, 2007), 164.

13 John Arquilla and David Ronfeldt, eds., Networks and Netwars: The Future of Terror, Crime, and Militancy (Santa Monica, CA.: RAND, 2001).

14 Andreas and Nadelmann, Policing the Globe. 
tary activities is not the defeat and elimination of an adversary, but the creation of a safe environment for a comprehensive and inclusive post-conflict political and social order. ${ }^{15}$

Generally, troops are not allowed to arrest citizens. Their role is mainly confined to supporting the police by deterring violence, providing logistical support and intelligence, ${ }^{16}$ and training specialized police forces in skills such as sharp-shooting. But the line between support and direct involvement in law enforcement is often blurry, and may not exist at all, as is most dramatically the case in peace operations.

In internal wars, serious crime is rampant. ${ }^{17}$ Also, problems linger on as war-torn countries make the transition to volatile peace. The resources of international military forces usually dwarf the resources of civilian actors, especially in terms of personnel and equipment such as surveillance equipment, weaponry, and transport capabilities that may be needed to apprehend sophisticated, well-armed individuals and groups committing serious crimes. Also, the military may be the first international actor to move into a post-war country in large numbers, and may be the only security actor in the arena for some time. ${ }^{18}$ Moreover, it is often difficult to distinguish between "normal criminals," who are best dealt with by the police, and suspects who undermine a safe and secure environment, and are therefore of interest to the military. For instance, those who have committed war crimes may continue to be involved in organized illegal activities (such as weapons smuggling) after the cessation of hostilities, and may also perpetuate inter-ethnic violence. The main task of the military is to establish a safe and secure environment so that civilian agencies can proceed with reconstruction, the rebuilding of the economy, the strengthening or creation of indigenous state institutions, peace-building, and the arrest and prosecution of suspected criminals. In practice, however, the onus of fighting crime tends to fall on the military.

Military involvement in law enforcement is problematic because, as mentioned above, the military is generally ill equipped and ill trained for this task. There is no lack of calls for a more proactive military stance. ${ }^{19}$ Yet, the military does not relish policing, regarding it as "mission creep" that confuses military functions and undermines morale. ${ }^{20}$ As Robert Perito writes, "military forces are unwilling to tackle situations

15 Hans-Georg Ehrhart and Albrecht Schnabel, "Changing International Relations and the Role of the Military in Post-Conflict Peacebuilding Operations," $S+F$, Sicherheit und Frieden 22:1 (2004): 10 .

16 Zentrum für Internationale Friedenseinsätze, "International and Local Policing in Peace Operations: Lessons Learned and the Way Forward to Integrated Approaches," report presented at the $8^{\text {th }}$ International Berlin Workshop (14-16 December 2006), 96.

17 John Mueller, The Remnants of War (Ithaca, NY: Cornell University Press, 2004).

18 Rachel Bronson, "When Soldiers Become Cops," Foreign Affairs 81:6 (2002): 122-32.

19 See, among others, Seth G. Jones, Jeremy M. Wilson, Andrew Rathmell, and K. Jack Riley, Establishing Law and Order After Conflict (Santa Monica, CA: RAND, 2005), 225; and Kimberly Marten, "Statebuilding and Force: The Proper Role of Foreign Militaries," Journal of Intervention and Statebuilding 1:2 (2007): 231-47.

20 For an early treatment of this issue, see Morris Janowitz, The Professional Soldier: A Social and Political Portrait (Glencoe, IL: The Free Press, 1960), 419. 
that involve controlling civil disturbances and law enforcement." ${ }^{21}$ In the U.S. military, fear of mission creep results from previous experiences in Vietnam and Somalia, as well as the fact that, while wars can be won, crime-fighting is a continuous task. ${ }^{22}$ This stance has permeated peace operations in general, given the preponderant role of the U.S. in international security.

Direct military participation in law enforcement is problematic for another reason: it runs counter to the SSR objective of separating military from policing work. Such a separation is a precondition for democratic governance, as blurred responsibilities make it difficult to hold security actors accountable. A separation is particularly vital in countries that are emerging from internal warfare. In the Balkans and elsewhere, paramilitarized police - sometimes in cooperation with military forces and non-statutory paramilitary groups - committed numerous human rights abuses. Fostering public trust in the police therefore requires de-militarizing the police, as well as curtailing the remit of the military. From this perspective, the undue involvement of foreign military forces risks undermining the credibility of SSR efforts; international actors cannot preach one thing and do the opposite.

Drawing the military into the law enforcement realm therefore bears considerable risks and costs. But international intervention in the Balkans shows that the costs of failing to fight crime exceed those of expanding the military task spectrum. Without law enforcement, stabilization, development, and peace-building will fail. Bosnia and Kosovo show that unsystematic military involvement in law enforcement stands in the way of protecting citizens of war-torn countries from serious crime.

\section{NATO and the EU in Bosnia}

The military presence in post-war Bosnia was massive. NATO deployed tens of thousands of soldiers as part of the Implementation Force (IFOR), followed by the Stabilization Force (SFOR). The aim of these missions was to create a safe and secure environment and to implement the military provisions of the Dayton Peace Accords. NATO made quick progress with regard to these provisions, but troop-contributing states neglected law enforcement, clinging to an overly restrictive interpretation of the IFOR/SFOR mandate. Consequently, especially during the early period after Dayton, they failed to devise Rules of Engagement (RoE) that would have allowed soldiers to put pressure on those engaged in serious criminal activity.

Bosnia in the 1990s was a devastated country. Many of those who had benefited from the war remained in powerful positions after the war, and new entrepreneurs came to the fore as well. A public security gap quickly opened up, resulting from a confluence of factors. First, NATO was reluctant to become engaged in law enforcement. ${ }^{23}$

21 Robert Perito, Where is the Lone Ranger When We Need Him? America's Role for a Postconflict Stability Force (Washington D.C.: United States Institute of Peace Press, 2004), 5.

22 Alice Hills, "The Inherent Limits of Military Forces in Policing Peace Operations," International Peacekeeping 8:3 (2001): 81; Mueller, The Remnants of War, 22.

23 Jane M.O. Sharp, “Dayton Report Card,” International Security 22:3 (1997/1998): 101-37. 
Second, civilian policing was weak; the United Nations' International Police Task Force (IPTF) deployed late, and suffered from a lack of capacities (for instance, IPTF officers were unarmed). ${ }^{24}$ Third, indigenous security forces represented the main sources of insecurity.

The reluctance of IFOR and the first rotations of SFOR to take an active role in fighting crime manifested itself in various ways. NATO failed to arrest suspected war criminals indicted by the International Tribunal for the Former Yugoslavia (ICTY). This stance was motivated by the fear that such operations would trigger public unrest and complicate force protection. NATO was also reluctant to put pressure on paramilitary police units, which continued to harass citizens and impeded freedom of movement, as well as illicit intelligence agencies affiliated with nationalist parties. Organized crime was even lower on NATO's priority list. The difficulty the military faced in filling security gaps was most evident with regard to crowd and riot control. Numerous times, mobs attacked members of other ethnic groups (especially returning refugees), as well as international actors, including NATO soldiers. The evacuation of Serbian neighborhoods in Sarajevo in early 1996 was an early indicator of NATO's unwillingness to intervene in violence that remained below the threshold of war.

NATO member states slowly came to realize that a withdrawal from Bosnia was not feasible in the absence of significant progress in the civilian realm. Troops thus began to arrest suspected war criminals, and to improvise against rioters and "ethnic cleansers." But their performance varied across and even within the various national contingents. Generally, troops were not trained and equipped to engage in crowd and riot control, and even less so in securing evidence on crime. Gendarmerie forces, deployed in 1998 as Multinational Stabilization Units (MSUs), were sometimes able to defuse tension or to intervene by way of well-calibrated use of force. But these units were under-utilized in areas where they had a competitive advantage (such as riot control and operations against organized crime), since commanders of regular military forces did not quite understand the role and structure of gendarmerie forces. ${ }^{25}$ Equally problematic were the national caveats imposed by troop-contributing countries that limited the multinational military's ability to support law enforcement. In some cases, the military as well as civilian institutions even exacerbated crime, as was the case with the human trafficking trade that thrived not least due to demand for commercial sex from foreigners. ${ }^{26}$

The fight against serious crime was further hampered by insufficient cooperation and coordination between military and civilian actors, reflecting different mandates,

24 For scathing criticism of the UN's actions in Bosnia, see European Stability Initiative report On Mount Olympus: How the UN Violated Human Rights in Bosnia and Herzegovina, and Why Nothing Has Been Done to Correct It (Berlin, Brussels, Istanbul: ESI, 10 February 2007); available at www.esiweb.org/index.php?lang=en\&id=156\&document_ID=84.

25

26 Perito, Where is the Lone Ranger When We Need Him?

Human Rights Watch, "Hopes Betrayed: Trafficking of Women and Girls to Post-Conflict Bosnia and Herzegovina for Forced Prostitution," Human Rights Watch Reports 14:9 (2002); available at www.hrw.org/reports/2002/bosnia/. 
standard operating procedures, and identities. The "Green Box/Blue Box" concept was conceptually innovative, but in practice it proved difficult to ensure that the military (safeguarding the Green Box) and the police (having command over the Blue Box) complemented one another. Furthermore, NATO collected impressive amounts of information and intelligence, but the sharing of this material was haphazard, and the military made too few efforts to collect it in a way that made it useful as evidence in criminal cases. International and Bosnian judges and prosecutors therefore lacked vital clues. The feeble, ad hoc nature of civil-military relations was indicated by the importance of personal relationships, reflecting a lack of institutionalized cooperation and institutional learning. When military and civilian officials were proactive, shared the same views, and received proper guidance from headquarters, efforts against serious crime were stepped up; if not, the opposite was the case.

One paradox of the international intervention in Bosnia was that the military became more proactive as a crime fighter at a time when doing so had become less pressing. Crucial opportunities were lost in the immediate years after Dayton. Yet by the beginning of the new millennium, as inter-ethnic crime had become less pervasive and as organized criminal groups had begun to focus more on business crime than on violent crime, the military was taking a more proactive stance. In other words, there was no linear decrease in military activity. On the contrary, many Bosnians criticized international actors for trying to tackle crime too late. ${ }^{27}$

The belated nature of this activism became most obvious when, in late 2004, the European Union Force (EUFOR) replaced SFOR (in late 2003, the European Union Police Mission [EUPM] had replaced the IPTF). EUFOR, under its British commander David Leakey, stressed that suspected war criminals were benefiting from organized crime. Also, Leakey perceived a need to bolster Bosnian security forces, and to reassure the population that crime would not go unpunished. EUFOR, during its first mandate, therefore staged numerous operations against crimes such as illegal logging. ${ }^{28}$ Some operations were arguably questionable with regard to the principles of proportionality (the appropriate use of security instruments in relation to a risk) and subsidiarity (the primacy of the police in internal security matters). It must be noted, however, that EUFOR's activism came at a time when the EUPM was still largely ineffectivenot least because its initial mandate did not cover organized crime - and when the Bosnian police was much too dependent on international support. Yet this increased level of military activism found some domestic support. Thus, the gendarmerie forces of EUFOR, the Integrated Police Units (IPU), staged numerous raids on the homes of suspected war criminals, and arrested several of them.

By 2006, EUFOR, EUPM, and Bosnian institutions complemented one another better than had previously been the case. EUFOR insisted on the primacy of the police in most security areas. Still, its role remained important. For instance, EUFOR pro-

27 See, for example, an op-ed by Zija Dizdarević in Oslobođenje (Sarajevo) (25 November 2007).

28 Cornelius Friesendorf and Susan E. Penksa, "Militarized Law Enforcement in Peace Operations: EUFOR in Bosnia \& Herzegovina,” International Peacekeeping 15:5 (2008): 677-94. 
vided training and equipment to Bosnian institutions, such as the State Investigation and Protection Agency (SIPA). Close relations between the military and policing agencies are problematic from an SSR point of view, due to the risk of transferring military (or, in the case of the IPU, paramilitary) thinking and behavior to those receiving support. However, EUFOR's more restrained role now prevented the shaping of police doctrine ${ }^{29}$ the EUPM, despite the absence of executive competencies, was now clearly the most dominant international actor in law enforcement in Bosnia.

This brief overview of international intervention in post-Dayton Bosnia underlines the ambiguities that characterized the situation there regarding how to fight criminal activity. It took NATO too long to acknowledge the need to counter the nefarious activities of those committing or enabling serious crimes. EUFOR tried to fill the civilian law enforcement vacuum, directly and on the operational level. On the positive side, both SFOR and EUFOR became more systematic in their crime-fighting efforts over time, revealing individual learning and, to some extent, institutional learning. One sign was that regular military forces came to employ gendarmerie forces more systematically. ${ }^{30}$ To be sure, as the more violent forms of serious crime were partially replaced by business crime - against which military instruments (with some exceptions, such as the surveillance tools used by the IPU) were largely ineffective-military support to law enforcement became less pressing and less useful.

\section{NATO in Kosovo}

As in Bosnia, the fight against serious crime challenged the stabilization of Kosovo. In some ways, the effort to combat crime in Kosovo was trickier than in Bosnia. Following the Kumanovo agreement stipulating the withdrawal of Yugoslav/Serbian forces from the disputed province (and later state), NATO's Kosovo Force (KFOR) moved into a wasteland that had neither any functional infrastructure nor any statutory indigenous security forces. KFOR was a formidable force, yet it was primarily configured to be prepared for warfare against Serbia, in case the latter refused to withdraw or attacked after withdrawing across the demarcation line. Yet it quickly became clear that the main problem in Kosovo was public insecurity.

The public security gap resulted, first, from local conditions. Post-war Kosovo, especially in 1999, was a very violent place. There was much factional fighting among Kosovo Albanians; in addition, Serbs and members of other minority groups came under attack from juvenile arsonists as well as members of the officially disbanded Kosovo Liberation Army (KLA). In response, Serbs created their own paramilitary armed groups, the most famous of which were the "bridge watchers" in the divided city of Mitrovica. The continuation of ethnic violence was fanned by the presence of numerous suspected war criminals. Most pressing, however, was the need to check organized crime. The war in Kosovo had been a criminalized war. Serbian paramilitaries were partially economically motivated, while the KLA profited from the drug trade.

29 Author interviews with international and Bosnian officials, Sarajevo, 2007-09.
30 Author interview with a EUFOR officer, Sarajevo, July 2008. 
After the war, the smuggling and trafficking of drugs, weapons, and other goods continued unabated, and to some degree increased, as was also the case with human trafficking. ${ }^{31}$

Second, a security gap arose since — once again — the civilian police deployed too late and too light. The United Nations Interim Administration in Kosovo Police (UNMIK Police) had executive powers, and included gendarmerie forces. But during the crucial immediate post-war period, only KFOR was present in most parts of Kosovo. An equally grave problem was the lack of a functional criminal justice system, as well as confusion over what laws were to be enforced.

Third, KFOR was a formidable military force, but its equipment, training, and command structures were ill suited for coping with smugglers or arsonists. Also, as in Bosnia, national caveats and the micromanagement of troops by capitals and military headquarters hamstrung the ability of contingents to respond quickly to criminal activity on the ground. Despite these obstacles, many soldiers improvised in admirable ways, quickly acquiring and applying basic policing skills. ${ }^{32}$ KFOR was thus able to somewhat check the continuation of inter-ethnic crime. Also, specialized forces arrested several suspected war criminals. Yet the willingness to risk military mission creep varied across sectors, and in several cases the military was accused of violating human rights. Most notoriously, the United States detained suspects in a prison facility inside the U.S. Army's Camp Bondsteel. KFOR's response to accusations of human rights violations was that it had no choice but to use extraordinary measures, given the lack of a functioning policing and criminal justice system. ${ }^{33}$

KFOR's problems in coping with serious crime came to the fore during the March 2004 riots, which led to the death of nineteen civilians. ${ }^{34}$ When large crowds attacked members of rival ethnic groups, as well as their homes and religious sites, during two days of partially orchestrated violence, NATO was taken by surprise, as were other international actors. The riots revealed that NATO forces had insufficient information and intelligence gathering capabilities, a lack of riot control training and equipment, bad coordination within and across military sectors, and deficient military-police cooperation. They also underlined the risks of transferring authority to indigenous security forces too quickly, as some officers of the Kosovo Police Force (KPS) reportedly participated in the violence.

31 See Ian Traynor, "NATO Force 'Feeds Kosovo Sex Trade'," The Guardian (7 May 2004).

32 Thijs W. Brocades Zaalberg, Soldiers and Civil Power: Supporting or Substituting Civil Authorities in Modern Peace Operations (Amsterdam: Amsterdam University Press, 2006), Part IV.

33 Roger F.M. Lorenz, "The Rule of Law in Kosovo: Problems and Prospects," Criminal Law Forum 11:2 (2000): 132. See also Clive Baldwin, "Implementation Through Cooperation? Human Rights Officers and the Military in Kosovo, 1999-2002," International Peacekeeping 13:4 (2006): 497.

34 International Crisis Group, "Collapse in Kosovo," ICG Europe Report No. 155 (22 April 2004); available at www.crisisgroup.org/en/regions/europe/balkans/kosovo/155-collapse-inkosovo.aspx. 
KFOR, which had handed over some powers to the KPS before the riots, subsequently became more circumspect in its dealings with the KPS. ${ }^{35}$ Moreover, crowd and riot control now became a central preoccupation of KFOR, and the authority of Commander KFOR in Pristina was strengthened, to allow him to quickly respond to violence across Kosovo. KFOR also continued to support the police by establishing checkpoints and security perimeters, and also by providing tips to UNMIK Police and the Kosovo Police Force (KPS). Indeed, direct cooperation between KFOR and the KPS increased again, following the lull that occurred after the March 2004 riots. The extent and type of cooperation varied across KFOR's Multinational Task Forces (MTF), with commanders at times reluctant to become mired in policing tasks. But overall, KFOR played a prominent law enforcement role. For instance, as security forces stepped up controls of the main roads into and out of Kosovo, smugglers used animal caravans to cross the rugged frontiers. By early 2007, KFOR was therefore beginning to increase off-road joint patrols with customs agencies - eight years after moving into the province. ${ }^{36}$

One of the most active crime-fighting elements of KFOR were the Multinational Specialized Units (MSUs). As in Bosnia, these were primarily Italian Carabinieri. These units raided houses to collect weapons, put up checkpoints to search for smuggled goods as well as to intercept wanted individuals, and provided surveillance support to the KPS. But generally, KFOR did not relish its law enforcement role, with officers deploring the lack of effective civilian policing structures. ${ }^{37}$ There were also specialized elements, such as J2 and members of an Intelligence, Surveillance, and Reconnaissance (ISR) unit that helped put pressure on individuals suspected of serious crimes. Even regular military units had little choice but to engage in law enforcement. As in Bosnia, the military as well as donor governments understood that the stabilization of Kosovo and the withdrawal of military forces depended on progress being made against serious crime. UNMIK was spread too thin to systematically position itself between NATO and the KPS - in contrast to Bosnia where, starting in 2006, EUPM coordinated EUFOR support to Bosnian law enforcement institutions. While the KPS grew in size and competence over time, it still lacked the capacities to replace international actors (plus, the remit of the KPS was limited by the reserve powers of UNMIK).

Another reason for KFOR's involvement in law enforcement was the undefined nature of serious crime in post-war Kosovo. KFOR was responsible for opposing those actors that posed a threat to a safe and secure environment. Yet where this military task ended and where normal policing began was open to debate, and depended much on local security conditions. For instance, one person could be accused of inter-ethnic crime as well as organized crime and corruption. The most prominent suspects were included in a target list, to which both selected military and civilian international actors

35 Author interview with former KFOR officer, October 2008.

36 Confidential international intelligence report, January 2007.

37 Author interviews with soldiers in four out of the five MTFs and at KFOR headquarters, 2007-09. 
had access; KFOR assets such as the ISR unit were tasked with observing some of these suspects. KFOR also had a role to play in crowd and riot control. Riots could easily escalate into quasi-military confrontations, in which some demonstrators would use weapons such as automatic rifles and hand grenades. Regular KFOR troops therefore had to constitute the last line of defense, backing up the KPS, civilian police, and the MSUs. Thus, ten years after the end of the war, a foreign military force was still being employed for riot control. ${ }^{38}$

A lack of conclusive data makes it difficult to assess the effectiveness of international crime fighting in post-war Kosovo. Yet it seems that the overall balance sheet is negative. Numerous sources underline the ongoing role of Kosovo as a site of criminal activity (e.g., as a hub of transnational drug trafficking around the time of independence). ${ }^{39}$ UNMIK largely failed to successfully prosecute suspects, reinforcing cynicism among the population in Kosovo regarding the political will of "internationals" to put pressure on local strongmen and corrupt officials.

KFOR was partly responsible for an unsystematic approach to fighting crime. For instance, relations were often tense between the MSU and MTF officers, with the latter fearing that MSU operations such as raids on houses would upset stability in their respective areas of responsibility. ${ }^{40}$ Yet these problems paled in comparison to the troubled relations between KFOR and civilian actors. For instance, after the declaration of independence, the northern sector of Kosovo remained largely un-policed for several months. KFOR was reluctant to engage smugglers and traffickers; the UNMIK Police were transferring responsibilities to the European Union Rule of Law Mission (EULEX); yet EULEX, not being accepted by Serbia (nor by many Serbs in Kosovo), was unable to operate in the Serb-dominated north; and the KPS was split along ethnic lines, with Serbian KPS officers boycotting the institution. Cooperation problems also hampered efforts to prevent and quell inter-ethnic violence. The riots in Spring 2008 in Mitrovica, during which one UNMIK police officer was killed, raised questions as to the ability of international actors to apply the lessons learned during the March 2004 riots.

Crime-fighting in Kosovo was thus fraught with problems. One reason was that law enforcement depended too much on military assets and the preparedness of civilian and military decision makers to use them. KFOR fared better in this regard than IFOR and SFOR. Also, NATO made efforts to learn from its failures in Kosovo. However, this learning process was hampered by the rotation of military personnel, divergent national military cultures and procedures, secrecy provisions, and fear of military mission creep.

38 "EULEX/KFOR Fire Shock Bombs, Rubber Bullets and Tear Gas to Disperse Serbs," KosovoCompromise (30 April 2009); available at www.kosovocompromise.com/cms/item/ latestnews/en.html?view=story\&id $=1945 \&$ sectionId $=1$.

39 European Commission, "Kosovo (Under UNSCR 1244/99) 2008 Progress Report," Commission Staff Working Document, COM(2008) 674, Brussels (5 November 2008): 52-53.

40 Author interviews with MTF officers, 2008. 
Problems in fighting crime should not only (and not even primarily) be laid at the door of NATO. A lack of accountable law enforcement, for instance, reflected the complexity of security sector governance in post-war Kosovo. The presence and interaction of numerous international and domestic actors, both military and civilian, created, in the words of a EULEX intelligence official, a "massive gray area," where overlapping competencies hampered any effort to assign responsibility for ineffective law enforcement. ${ }^{41}$ Also, failures in the fight against crime resulted from weak civilian planning and policy implementation. Most notably, UN member states and UNMIK largely failed to effectively prevent a security gap from emerging, and then failed to fill it by way of effective and efficient policing that was in line with democratic standards. The list of complaints against the international presence in Kosovo is long indeed. UN member states and UNMIK were accused of politically motivated interference in law enforcement, corruption and collusion, incompetence, and a lack of accountability. ${ }^{42}$ Over the years, UNMIK's reputation increasingly suffered. KFOR, on the other hand, was held in relatively high esteem by the population of Kosovo. This is an important caveat when criticizing NATO's performance in Kosovo.

\section{Conclusion: Improving Efforts Against Serious Crime}

Since the end of the Cold War, armed forces have been transformed. A new risk environment, along with technological innovations, has led countries to restructure, professionalize, and, in many cases, downsize their militaries. The task spectrum of the "postmodern military" is much broader than had been the case during the Cold War, when the military was preoccupied with defending territories against external military threats. ${ }^{43}$ Law enforcement is one of the many non-traditional military activities that the military is increasingly being asked to support or undertake, in addition to counterinsurgency, counter-terrorism, limited intervention, and disaster relief operations.

The importance of supporting law enforcement and fighting serious crime has by now been acknowledged as a necessary condition for stabilizing war-torn countries. ${ }^{44}$ In practice, however, security gaps have time and again opened up in post-war environments, not least because civilian and military decision makers have not sufficiently prepared armed forces to support or undertake law enforcement. ${ }^{45}$

41 Author interview, Pristina, November 2008.

42 See Maciej Zaremba, "Series on Kosovo," Dagens Nyheter (Stockholm) (25 June 2007); available at http://www.dn.se/kultur-noje/debatt-essa/part-1-report-from-unmikistan-land-ofthe-future-1.732443.

43

Charles C. Moskos, John Allen Williams, and David R. Segal, "Armed Forces after the Cold War," in The Postmodern Military: Armed Forces after the Cold War, ed. Charles C. Moskos, John Allan Williams, and David R. Segal (New York: Oxford University Press 2000), 1-13.

44 The U.S. Army/Marine Corps Counterinsurgency Field Manual (Chicago: University of Chicago Press, 2007), 360-61.

45 Robert Perito, "Police in Peace and Stability Operations," International Peacekeeping 15:1 (2008): 51-66. 
The cases of the military's experience in fighting crime in Bosnia and Kosovo illustrate how this shortcoming has marked international intervention in the Balkans. The reticence of civilian and military decision makers to employ the military in the fight against serious crime has enabled spoilers of peace to become entrenched, both economically and politically. Yet military participation in law enforcement has had its drawbacks, too. To the extent that progress was made, most successes were tactical, not strategic (although it must be noted that even the police only rarely reap strategic victories over crime). Normatively, an ambiguous military-police-intelligence nexus ran counter to the SSR objective of clearly defining the roles of security forces, and of putting the police at the forefront in the fight against crime. Not before 2006 did international actors create viable military-police networks in Bosnia. In Kosovo, military and police tasks were still awaiting proper delineation ten years after the end of the war. Such blurring of responsibilities weakens the normative power of international actors vis-à-vis domestic actors. After all, if the former want to be regarded as credible, they must practice what they preach. However, the failure to adhere to SSR principles is arguably an acceptable cost, in comparison to the costs of not employing the military against serious crime.

Unsystematic management of gray areas between the remits of the police and military is not limited to the Balkans; it has undermined stabilization efforts in many other countries as well. The most dramatic recent cases in this regard have been Iraq and Afghanistan. In both countries, the failure of international actors to ensure public order following the toppling of a regime undermined the legitimacy of both international actors and incipient state institutions, and fanned the insurgencies that engulfed the two countries after a brief period of deceptive peace.

The question, then, is how to improve the performance of international actors in the fight against serious criminal activity after full-scale war operations have ended. There are neither panaceas nor universal approaches, given that conditions and resources vary across peace operations, and that militarized law enforcement involves practical and normative trade-offs. Yet it is possible to lay out the fundamentals of a policy framework. $^{46}$

States intervening in war-torn countries should fight serious crime immediately. Postponing such efforts offers short-term advantages in terms of stability and force protection, but the long-term costs are greater. This implies that more forces capable of operating in civil-military gray areas, such as gendarmeries or Formed Police Units (FPU), are needed. ${ }^{47}$ Yet since these units are scarce, regular military forces will continue to be involved in law enforcement. Therefore, they will require new forms of training. Some skills can be taught within a day (e.g., how to avoid destroying criminal

46 For a more detailed analysis, see Friesendorf, The Military and Law Enforcement in Peace Operations, 150-61.

47 On FPU, see Benjamin Kwasi Agordzo, "Filling the 'Security Gap' in Post-conflict Situations: Could Formed Police Units Make a Difference?” International Peacekeeping 16:2 (August 2009): 287-94. 
evidence), while some will call for a more profound change in the military mindset. ${ }^{48}$ Among other tasks, troop-contributing states should:

- Formulate robust military mandates and Rules of Engagement that include law enforcement support as a military task

- Limit national caveats on the deployment of contributed troops

- Ensure good interoperability and command structures ${ }^{49}$

- Raise troop awareness about post-war problems, such as human trafficking

- Provide adequate equipment for crowd and riot control.

Cooperation between the military and civilian actors, especially the police and justice institutions, is crucial. The military can support the police in many ways, including by gathering information and intelligence and sharing it with relevant partners, or by establishing security perimeters. ${ }^{50}$ The trick is to strike a balance between involving the military in law enforcement and respecting the principles of security sector reform. The right training and equipment can help ensure respect for the proportional use of force. ${ }^{51}$ Careful planning is crucial in order to ensure the primacy of the police in internal security matters. This means that the military should not drive the reform of indigenous security forces, especially the police, to ensure civilian oversight and to prevent an undue militarization of institutional doctrines. ${ }^{52}$

There also should be a decrease of military involvement in crime fighting over time, with responsibilities being transferred from the military to police. As early as 2000 , the UN pushed for "methodologies and standard operating procedures of the transition from the provision of security by international military to international police

48 Mary Kaldor and Andrew Salmon, "Military Force and European Strategy," Survival 48:1 (2006): 31 .

49 See Dale Stephens, "The Lawful Use of Force by Peacekeeping Forces: The Tactical Imperative," International Peacekeeping 12:2 (2005): 157-72. On different command structure options, see Michael J. Dziedzic and Robert M. Perito, Haiti: Confronting the Gangs of Portau-Prince, USIP Special Report 208 (Washington D.C.: United States Institute of Peace, September 2008), 12; and Zentrum für Internationale Friedenseinsätze, "International and Local Policing in Peace Operations," 43.

50 See Oliver Mintz, "Focused Operations against Organized Crime in a Mature Peace Operations Environment," Infantry Magazine 96:1 (2007): 38-45.

51 On proportionality, see Venice Commission, "Report on Democratic Control of the Armed Forces," adopted by the European Commission for Democracy Through Law (Venice Commission) at its $74^{\text {th }}$ Plenary Session, Venice, 14-15 March 2008, CDL-AD(2008)004 (Strasbourg: Council of Europe, 27 March 2008), 26; Mark Franken, Welche Polizeiaufgaben kann Militär übernehmen?, Interne Information zur Sicherheitspolitik (Vienna: Büro für Sicherheitspolitik des Bundesministeriums für Landesverteidigung, February 2006).

52 United Nations, Handbook on UN Multidimensional Peacekeeping Operations (New York: United Nations Best Practices Unit, 2003), 88. 
and finally to local police" in Bosnia. ${ }^{53}$ Yet interventions in Kosovo, Afghanistan, and elsewhere demonstrate the continuing challenges of putting lessons about divisions of labor, and crime fighting more generally, into practice. This is because conditions enabling systematic law enforcement may often be absent in post-conflict societies. These conditions pertain to post-war conditions, as well as the capacities of local and international actors. Post-war conditions structure the way international actors intervene in a country. When levels of violence are high, when basic infrastructure such as roads or housing are not available, and when it is unclear which laws are to be enforced, civilian police will have trouble operating. Military forces may therefore lead the fight against serious crime.

Domestic actors matter as well. Policing obviously suffers when police and the criminal justice sector lack capacity, or when corruption and criminal collusion are pervasive. These shortcomings often reflect historical and cultural legacies that are difficult to overcome in the aftermath of war. Weak or biased domestic law enforcement puts great strain on international military forces, by depriving the military as well as civilian police of the cooperation of vital domestic counterparts.

Last, the fight against serious crime, and the role of the military, hinges on international actors. These need to have the political will to enforce laws, adapt to environmental change, and learn from mistakes. The degree to which the military becomes involved depends very much on the presence and strength of civilian police and international criminal justice experts and practitioners. Many other factors play a role as well, such as the ability of states to deploy constabulary forces, to provide the right training and equipment, to devise appropriate mandates, and to ensure a commonality of purpose across the entire theatre. Moreover, the quality of law enforcement reflects the ability and willingness of international military and civilian institutions to gather and share information and intelligence, as well as interpersonal relationships, from the tactical to the strategic and diplomatic level.

In Bosnia and Kosovo, conditions conducive to systematic crime fighting were sometimes absent. This has been detrimental to international stabilization efforts. Yet in the Balkans, international actors have invested significant resources over a long period of time, and there are signs of institutional learning. Elsewhere, circumstances are less conducive to the fight against serious criminal activity. In Afghanistan, for instance, law enforcement obstacles include high levels of violence, the presence of numerous spoilers, the large size of the country, poverty, corruption, and a lack of institutional capacity. Yet even problems that international actors could more easily mitigate continue to hamper the effectiveness of international intervention. Most importantly, recruiting and deploying more and better-prepared civilian police remains problematic, even though it is widely recognized as a precondition for more systematic intervention. For example, by 2010, Germany was still struggling with sending more police officers as mentors and trainers to Afghanistan. Candidates who want to go to

53 United Nations, "Report of the Secretary-General on the Implementation of the Report of the Panel on United Nations Peace Operations" (20 October 2000), Paragraph 96f; available at www.un.org/peace/reports/peace_operations/docs/55_502e.pdf. 
Afghanistan leave policing gaps at home, making their superiors reluctant to let them go. Also, while pay has been increased, participating in peace operations still offers few career incentives. ${ }^{54}$ Not least due to the shortage of international police, international military forces are deeply embroiled in law enforcement in Afghanistan, and in propping up the Afghan National Police.

Given these obstacles, international intervention in war-torn countries will remain messy. It is inevitable that nations that contribute troops to international missions will have to rethink the role of the military, and gear it towards a law enforcement role during periods in which policing structures are weak. Preparing for the fight against serious crime should be part of the larger project of military transformation, in order to enable the military to better protect people. Dag Hammarskjöld said that, although peacekeeping is not the job of soldiers, only soldiers can do it. While law enforcement is not a military job either, often only soldiers can do it.

54 Interviews with German police officers, 2010. 


\section{Bibliography}

Agordzo, Benjamin Kwasi. "Filling the 'Security Gap' in Post-conflict Situations: Could Formed Police Units Make a Difference?" International Peacekeeping 16, no. 2 (2009): 287-94.

Andreas, Peter, and Ethan Nadelmann. Policing the Globe: Criminalization and Crime Control in International Relations. Oxford: Oxford University Press, 2006.

Arquilla, John, and David Ronfeldt. Networks and Netwars: The Future of Terror, Crime, and Militancy. Santa Monica, CA.: RAND, 2001.

Bayley, David H., and Robert M. Perito. The Police in War: Fighting Insurgency, Terrorism, and Violent Crime. Boulder, CO: Lynne Rienner, 2010.

Born, Hans. IPU-DCAF Handbook on Parliamentary Oversight of the Security Sector: Principles, Mechanisms and Practices. Geneva: DCAF, 2003.

Bronson, Rachel. "When Soldiers Become Cops." Foreign Affairs 81, no. 6 (2002): 122-32.

Development, US Agency for, U.S. Department Defense, and U.S. Department State. "Security Sector Reform." Connections: The Quarterly Journal 9, no. 1 (2009): 113-129.

Dziedzic, Michael J., and Robert M. Perito. Haiti: Confronting the Gangs of Port-auPrince In USIP Special Report. Washington D.C.: United States Institute of Peace, 2008.

Ehrhart, Hans-Georg, and Albrecht Schnabel. "Changing International Relations and the Role of the Military in Post-Conflict Peacebuilding Operations." S+F, Sicherheit und Frieden 22, no. 1 (2004): 10.

EULEX/KFOR Fire Shock Bombs, Rubber Bullets and Tear Gas to Disperse Serbs. Kosovo-Compromise, 2009.

Franken, Mark. Welche Polizeiaufgaben kann Militär übernehmen?, Interne Information zur Sicherheitspolitik. Vienna: Büro für Sicherheitspolitik des Bundesministeriums für Landesverteidigung, 2006.

Friesendorf, Cornelius, and Susan E. Penksa. "Militarized Law Enforcement in Peace Operations: EUFOR in Bosnia \& Herzegovina." International Peacekeeping 15, no. 5 (2008): 677-94.

Friesendorf, Cornelius. "The Military and Law Enforcement." In Peace Operations: Lessons from Bosnia-Herzegovina and Kosovo. Vienna and Geneva: LIT and DCAF, 2010.

Group, International Crisis. Collapse in Kosovo In ICG Europe Report., 2004.

Haltiner, Karl W.. "Policemen or Soldiers? Organizational Dilemmas of Armed Forces in Peace Support Operations." In The Challenging Continuity of Change and the Military: Female Soldiers, Conflict Resolution, South Africa, 359-84. Strausberg: Sozialwissenschaftliches Institut der Bundeswehr, 2001. 
Handbook on UN Multidimensional Peacekeeping Operations In Best Practices Unit. New York: United Nations, 2003.

Hills, Alice. "The Inherent Limits of Military Forces in Policing Peace Operations." Interna-tional Peacekeeping 8, no. 3 (2001).

Hopes Betrayed: Trafficking of Women and Girls to Post-Conflict Bosnia and Herzegovina for Forced Prostitution. Human Rights Watch Reports 14, no. 9 (2002).

International and Local Policing in Peace Opera-tions: Lessons Learned and the Way Forward to Integrated Approaches. 8th International Berlin Workshop: Zentrum für Internationale Friedenseinsätze, , 2006.

Janowitz, Morris. The Professional Soldier: A Social and Political Portrait. New York, Free Press, 1960.

Jones, Seth G., Jeremy M. Wilson, Andrew Rathmell, and Jack K. Riley. Establishing Law and Order After Conflict. Santa Monica, CA: RAND, 2005.

Kaldor, Mary, and Andrew Salmon. "Military Force and European Strategy." Survival 48, no. 1 (2006): 31.

Kosovo (Under UNSCR 1244/99) 2008 Progress Report In Commission Staff Working Document. Brussels: European Commission, 2008.

Kraska, Peter B.. "Militarization and Policing - Its Relevance to 21st Century Police." Policing 1, no. 4 (2007): 501-13.

Lorenz, Roger F. M.. "The Rule of Law in Kosovo: Problems and Prospects." Criminal Law Forum 11, no. 2 (2000): 132.

Lutterbeck, Derek. "Between Police and Military: The New Security Agenda and the Rise of Gendarmeries." Cooperation and Conflict 39, no. 1 (2004): 45-68.

Marten, Kimberly. "Statebuilding and Force: The Proper Role of Foreign Militaries." Journal of Intervention and Statebuilding 1, no. 2 (2007): 231-47.

Mintz, Oliver. "Focused Operations against Organized Crime in a Mature Peace Operations Environment." Infantry Magazine 96, no. 1 (2007): 38-45.

Mobekk, Eirin. Identifying Lessons in United Nations International Policing Missions In DCAF Policy Paper. Geneva: Geneva Centre for the Democratic Control of Armed Forces, 2005.

Moskos, Charles C., John Allen Williams, and David R. Segal. "Armed Forces after the Cold War." In The Postmodern Military: Armed Forces after the Cold War, 1-13. New York: Oxford University Press, 2000.

Mueller, John. The Remnants of War. Ithaca, NY: Cornell University Press, 2004.

Oakley, Robert B., Michael Dziedzic, and Eliot M. Goldberg. Policing the New World Disorder: Peace Operations and Public Security. Washington D.C.: National Defense University Press, 1998. 
On Mount Olympus: How the UN Violated Human Rights in Bosnia and Herzegovina, and Why Nothing Has Been Done to Correct It. Berlin, Brussels, Istanbul: European Stability Initiative (ESI), 2007.

Perito, Robert. "Police in Peace and Stability Operations." International Peacekeeping 15, no. 1 (2008): 51-66.

Perito, Robert. Where is the Lone Ranger When We Need Him? America's Role for a Post-conflict Stability Force. Washington D.C.: United States Institute of Peace Press, 2004.

Rausch, Colette. Combating Serious Crimes in Postconflict Societies: A Handbook for Policymakers and Practitioners. Washington, D.C.: United States Institute of Peace Press, 2006.

Report of the Secretary-General on the Implementation of the Report of the Panel on United Nations Peace Operations. United Nations, 2000.

Report on Democratic Control of the Armed Forces. Venice: Venice Commission (74th Plenary Session), 2008.

Sharp, Jane M. O.. "Dayton Report Card." International Security 22, no. 3 (1998): 101-37.

Soldiers and Civil Power: Supporting or Substituting Civil Authorities in Modern Peace Operations. Amsterdam: Amsterdam University Press, 2006.

Stephens, Dale. "The Lawful Use of Force by Peacekeeping Forces: The Tactical Imperative." International Peacekeeping 12, no. 2 (2005): 157-72.

The OECD DAC Handbook on Security System Reform (SSR): Supporting Security and Justice. Paris: Organization for Economic Cooperation and Development (OECD), 2007.

The U.S. Army/Marine Corps Counterinsurgency Field Manual. Chicago: University of Chicago Press, 2007.

Traynor, Ian. "NATO Force 'Feeds Kosovo Sex Trade'." The Guardian (2004).

Zaremba, Maciej. Series on Kosovo. Stockholm: Dagens Nyheter, 2007.

Zimmermann, Doron. "Between Minimum Force and Maximum Violence: Combating Political Violence Movements with Third-Force Options." Connections: The Quarterly Journal 4, no. 1 (2005): 43-60. 